\title{
ANTIDIABETIC AND HYPOLIPIDEMIC EFFECT OF METHANOL EXTRACT OF STEREOSPERMUM COLAIS FRUIT IN STREPTOZOTOCIN INDUCED DIABETIC RATS
}

\author{
MD. Imran ${ }^{1}$, Mohib Khan ${ }^{2}$, Rashid Akhtar ${ }^{1}$, Sufiyan Ahmed ${ }^{1}$, Mohammed Rageeb ${ }^{3}$ \\ ${ }^{1}$ Department of Pharmaceutical Sciences, JJT University, (Rajasthan) India \\ ${ }^{2}$ Oriental College of Pharmacy, Sanpada, New Mumbai, (MS) India \\ ${ }^{3}$ Department of Pharmacognosy, Smt. S. S. Patil College of Pharmacy, Chopda, (MS) India
}

Received 12 June 2016; Review Completed 30 June 2016; Accepted 30 June 2016, Available online 15 July 2016

\begin{abstract}
:
Objective: To assess the antidiabetic and hypolipidemic properties of Stereospermum colais Fruit.

Methods: Acute toxicity test was done to check the toxicity of Stereospermum colais fruit methanol extract at three dose levels was administered orally to streptozotocin (STZ) $(40 \mathrm{mg} / \mathrm{kg}$ bw) induced diabetic rats for 15 days. The various parameters were studied including body weight, fasting blood glucose levels, plasma insulin, lipid profile, glycogen content, glycoslylated hemoglobin (HbAlc) and serum marker enzymes levels in normal, treated and diabetic rats. Histochemical analysis of pancreas was also carried out in normal treated and diabetic rats.

Results: The treatment group with the extract at three dose levels showed a significant increase in the liver, muscle glycogen and serum insulin level and a significant decrease in fasting blood glucose, glycosylated hemoglobin levels and serum marker enzyme levels. The total cholesterol and serum triglycerides levels were also significantly reduced and the high density lipoprotein level was significantly increased upon treatment with the Stereospermum colais Fruit methanol extract. Histochemical study of pancreas also confirmed the biochemical findings. Acute toxicity studies revealed the non-toxic nature of the Stereospermum colais Fruit methanol extract. Conclusions: The results of the experiments presented here suggest that methanol extract of Stereospermum colais Fruit exerts significant antidiabetic and hypolipidaemic effect in STZ induced diabetic rats.
\end{abstract}

Keywords: Stereospermum colais, Antidiabetic, Hypolipidemic, Fruit, streptozotocin.

\section{INTRODUCTION:}

Diabetes mellitus (DM) has been defined as a chronic disease with persistently elevated blood glucose concentration, leading to acute $r$ long term complications ${ }^{1}$. Globally, DM presents enormous and increasingly important public health issues. The prevalence of DM in all age groups was estimated to be $2.8 \%$ (170 million) in 2000 and the rate is expected to rise to $4.4 \%$ (366 million) in $2030^{2}$. The pharmacological agents currently used for treatment of type 2 diabetes include sulfonylureas, biguanide, thiazolidinedione and alpha glycosidase inhibitors. These agents, however, have restricted usage due to several undesirable side effects and fail to significantly alter the course of diabetic complications. Renewed attention to alternative medicines and natural therapies has stimulated new waves of research interest in traditional practices, and there is a need to look for more efficacious agents with lesser side effects. Presently, there is growing interest in herbal remedies due to the side effects associated with oral hypoglycemic agents for the treatment of diabetes mellitus ${ }^{3,4}$.

Stereospermum colais (Buch.-Ham.ex Dillw.) is commonly known as Mabberley, belonging to the family of Bignoniaceae. It is normally found in India, Myanmar, and Sri Lanka; in the Western Ghats- South, Central and south Maharashtra Sahyadris. In spite of its many uses (diarrhoea, cough, asthma, hiccough, bleedings, hyperacidity, vomiting, fever, general debility, rheumatism, malarial fever, wounds, burning sensation, heart disease), the antidiabetic, antiperoxidative and radical scavenging activities of this species have not been assessed, and its chemical composition is scarcely known ${ }^{5,6}$.

However, there are no reports on the antidiabetic activity of the plant. Hence this study was undertaken to evaluate the anti-diabetic activity of methanol extract of Stereospermum colais Fruit in sterptozotocin (STZ) induced diabetic rats. 


\section{MATERIALS AND METHODS:}

\section{Plant material:}

The Fruits of Stereospermum Colais were collected from Pathnur Ghat, Taluka Ardhapur, District Nanded, Maharashtra, India. Plant materials were authenticated from Dr. Arvind S Dhabe Dr, Babasaheb Ambedkar Marathwada University, Aurangabad. Collected plant material was dried in tray dryer at $55^{\circ} \mathrm{C}$ for $24 \mathrm{~h}$ and powdered. Herbarium was prepared according to International curatorial practices. Specimen was given a number by the plant identifying authority is 0780 (reference number Bet/2010-11).

\section{Preparation of extracts:}

The whole plant of Stereospermum colais Fruit was washed thoroughly with water to remove the soil particles, and then was air dried and powdered. One kilogram of plant material was extracted with methanol solvent $(2.5 \mathrm{~L}$ for each time). The filtrate was concentrated under reduced pressure at $40{ }^{\circ} \mathrm{C}$ and the extract was stored in a refrigerator at $4{ }^{\circ} \mathrm{C}$ for use in subsequent experiments.

\section{Chemicals:}

Sterptozotocin was obtained from Hetero Drugs, Hyderabad, India. Kits to estimate total cholesterol, triglycerides and HDL-cholesterol kit was purchased from Merck, Mumbai, India. All other chemicals were of analytical grade.

\section{Preliminary phytochemical screening of the extract:}

The preliminary phytochemical analysis was carried out for the Stereospermum colais Fruit methanol extract (SC methanol extract) using standard phytochemical methods ${ }^{7}$.

\section{Animals:}

Healthy adult Wister albino rats with body weight around $(170 \pm 5) \mathrm{g}$ at 60-70 days from birth and raised in the animal house at Oriental College of pharmacy, Navi Mumbai were used for the study. Housed individually in polypropylene cages, maintained under standard conditions in $12 \mathrm{~h}$ light and $12 \mathrm{~h}$ dark cyle at $(25 \pm 3)^{\circ} \mathrm{C}$, the rats were fed with standard rat pellet diet (Pranav Agro Industry Ltd., Maharashtra) and water. The study was approved by the animal ethical committee of the institute (1185/A/08/CPCSEA).

\section{Acute toxicity study:}

Healthy adult Wister albino rats of either sex starved overnight were divided into five groups $(n=6)$ and were orally fed with the SC methanol extract in increasing dose levels of $100 \mathrm{mg} / \mathrm{kg}$ bw, $500 \mathrm{mg} / \mathrm{kg}$ bw, $1 \mathrm{~g} / \mathrm{kg}$ bw, $3 \mathrm{~g} / \mathrm{kg}$ bw and $5 \mathrm{~g} / \mathrm{kg} \mathrm{bw}^{8}$. The animals were observed continuously for $2 \mathrm{~h}$ under the following profiles $^{9}$ (a) Behavioral profile: Alertness, restlessness, irritability and fearfulness; (b) Neurological profile: spontaneous activity, reactivity, touch response, pain response and gait; (c) Autonomic profile: defecation and urination. After a period of 24 and $72 \mathrm{~h}$ they were observed for any lethality or death.

\section{Oral glucose tolerance test (OGTT):}

The oral glucose tolerance test was performed in overnight $(18 \mathrm{~h})$ fasted normal rats ${ }^{10}$. Rats divided into three groups $(n=6)$ were administered drinking water, SC methanol extract at 50, 100, and $200 \mathrm{mg} / \mathrm{kg}$, respectively. Glucose $(2 \mathrm{~g} / \mathrm{kg})$ was fed $30 \mathrm{~min}$ after the administration of extracts. Blood was withdrawn from the retro orbital sinus under ether inhalation at 30, 60 and $120 \mathrm{~min}$ of glucose administered and glucose levels were estimated using a glucose oxidaseperoxidase method $^{11}$.

\section{Induction of diabetes mellitus:}

Diabetes mellitus was induced in overnight fasted adult Wister strain albino rats weighing $(170 \pm 5) \mathrm{g}$ by single intraperitoneal injection of freshly prepared STZ at dose of $40 \mathrm{mg} / \mathrm{kg}$ bw in $0.1 \mathrm{M}$ citrate buffer ( $\mathrm{pH}=4.5$ ). After seven days of STZ administration, blood glucose level was determined. Rats with blood glucose level above $200 \mathrm{mg} / \mathrm{dl}$ were considered diabetic and induced in the study.

\section{Experimental design:}

In the experiment a total of 36 rats (6 normal; 30 STZ diabetic surviving rats) were used. The rats were divided into six groups of six rats each.

Group I: Normal control rats; Group II: Diabetic control rats; Group III: Diabetic rats treated with SC methanol extract at dose of $50 \mathrm{mg} / \mathrm{kg}$ bw; Group IV: Diabetic rats treated with SC methanol extract at dose of $100 \mathrm{mg} / \mathrm{kg}$ bw; Group V: Diabetic rats treated with SC methanol extract at dose of $200 \mathrm{mg} / \mathrm{kg} \mathrm{bw}$; Group VI: Diabetic rats treated with Glibenclamide at dose of $600 \mu \mathrm{g} / \mathrm{kg}$ bw. The extract was dissolved in $2 \%$ tween 80 solutions and administered orally in Group III, Group IV and Group V for two weeks.

At the end of the study, the animals were euthanized between 0900-1100 h to minimize diurenal variation. Fasting blood glucose level was estimated by glucose oxidase-peroxidase method. The assay of insulin in the plasma of normal and diabetic rats was performed by enzyme-linked immunosorbent assay (ELISA) method. The glycogen level of liver and skeletal muscles was measured by anthrone method ${ }^{12}$. Glycosylated hemoglobin was estimated by the method of Sudhakar and Pattabiraman, $1981^{13}$. Lipid profile [total cholesterol, high density lipoprotein (HDL), cholesterol and triglyceride] levels in serum were determined according to the instructions of the manufacturer (Merck, Mumbai, India). Serum glutamic oxaloacetic transaminase (SGOT), serum glutamic-pyruvic transaminase (SGPT) and alkaline phosphatase (ALP) was determined by the method of Reitman and Frankel, $1957^{14}$.

\section{Histological studies:}

After blood sampling for the biochemical analysis, the animals were scarified, quickly dissected. Small slices of pancreases were taken and fixed in $10 \%$ formalin. 
The specimens were dehydrated in ascending grades of ethanol. Cleared in xylene and embedded in paraffin wax. Sections of $6 \mu \mathrm{m}$ in thickness were prepared and stained with haematoxylin and eosin and subjected to microscopical examination ${ }^{15}$.

\section{Statistical analysis:}

One-way ANOVA and Students t-test (SPSS program; version 11.5) were carried out to compare the data with the level of significance set at $P \leq 0.05$.

\section{RESULTS:}

Phytochemical analysis of SC methanol extract revealed the presence of Carbohydrate, Proteins, Sterols, Saponin, Coumarins, Lipid and flavonoids. The simple quantitative analysis of the extract was based on the intensity of colour change.

Acute toxicity studies showed the non-toxic nature of the SC methanol extract. There was no lethality or any toxic reactions found at any of the doses selected until the end of the study period. In OGTT, SC methanol extract, from $30 \mathrm{~min}$ onwards showed significant reduction in plasma glucose levels (Table 1).

Table 2 showed the changes in body weight of experimental rats at zero and final day of treatment. Significant decrease in body weight of diabetic control rats were observed when compared with normal control rats. However, significant increase in body weight was observed in SC methanol extract treated groups in dose dependent manner when compared with diabetic control rats.
Inductions of diabetes in the experimental rats were confirmed by the presence of a high fasting blood glucose level. The effect of the SC methanol extract on the fasting blood glucose level normal and STZ induced diabetic animals were presented in table 3 . At the end of $15^{\text {th }}$ day study SC methanol extract at 200 $\mathrm{mg} / \mathrm{kg}$ bw treated group reduced the fasting glucose level significantly $(46.32 \%)$ when compared with diabetic control.

Tables 4 and 5 showed the effect of SC methanol extract on serum insulin, glycosylated hemoglobin and liver and muscle glycogen content. Administration of SC methanol extract to diabetic rats for 15 days significantly increased the levels of serum insulin, liver glycogen content, muscle glycogen and significant decrease was observed in glycosylated hemoglobin when compared with diabetic control.

Table6 showed increased level of total cholesterol, triglycerides and decreased level of HDL-cholesterol in diabetic rats compared to normal control. Administration of SC methanol extract for 15 days significantly reduced the total cholesterol, triglycerides levels and significantly increased the HDL-cholesterol level when compared with diabetic rats.

The Table 7 showed the effect of administration SC methanol extract on serum marker enzymes. The concentration of SGOT, SGPT and ALP was increased in diabetes condition when compared with normal control. Administration of SC methanol extract and glibenclamide was found to keep the levels near to normal values.

Table 1: Effect of the SC methanol extract on OGTT in normal rats (Mean \pm SEM).

\begin{tabular}{|c|c|c|c|c|c|}
\hline $\begin{array}{c}\text { Groups } \\
(\mathbf{n}=6) \\
\text { Treatment }\end{array}$ & Treatment & \multicolumn{3}{|c|}{ Blood glucose (mg/dL) } \\
\cline { 3 - 6 } & & $0 \mathrm{~min}$ & $30 \mathrm{~min}$ & $60 \mathrm{~min}$ & $120 \mathrm{~min}$ \\
\hline I & Control $+2 \mathrm{~g} / \mathrm{kg} \mathrm{bw}$ glucose & $67.65 \pm 2.41$ & $146.04 \pm 1.42^{* *}$ & $132.59 \pm 1.29$ & $122.68 \pm 1.88$ \\
\hline II & SC $50 \mathrm{mg} / \mathrm{kgbw}+2 \mathrm{~g} / \mathrm{kg} \mathrm{bw}$ glucose & $65.97 \pm 1.28$ & $133.79 \pm 0.84^{* *}$ & $117.54 \pm 1.09^{* *}$ & $102.16 \pm 1.88^{* *}$ \\
\hline III & SC $100 \mathrm{mg} / \mathrm{kgbw}+2 \mathrm{~g} / \mathrm{kg}$ bw glucose & $64.79 \pm 1.27$ & $127.01 \pm 1.17^{* *}$ & $111.56 \pm 1.09^{* *}$ & $95.34 \pm 0.86^{* *}$ \\
\hline IV & SC $200 \mathrm{mg} / \mathrm{kgbw}+2 \mathrm{~g} / \mathrm{kg}$ bw glucose & $65.14 \pm 1.18$ & $122.63 \pm 1.56^{* *}$ & $101.66 \pm 0.90^{* *}$ & $75.83 \pm 1.76^{* *}$ \\
\hline $\mathbf{V}$ & $\begin{array}{c}\text { Glibenclamide } 600 \mu \mathrm{g} / \mathrm{kg} \text { bw }+2 \mathrm{~g} / \mathrm{kg} \\
\mathrm{bw}\end{array}$ & $65.82 \pm 1.27$ & $122.46 \pm 1.05^{* *}$ & $112.68 \pm 1.22^{* *}$ & $79.15 \pm 1.12^{* *}$ \\
\hline
\end{tabular}

* Values deviate significantly from diabetic control; ** Values deviate very significantly $(P \leq 0.05)$ when compared with diabetic control values.

Table 2: Effect of oral administration of SC methanol extract on body weight in STZ induced diabetic rats after 15 days (Mean \pm SEM).

\begin{tabular}{|c|c|c|c|}
\hline $\begin{array}{c}\text { Groups } \\
(\mathbf{n = 6 )} \\
\text { Treatment }\end{array}$ & Treatment & \multicolumn{2}{|c|}{ Body weight $(\mathbf{g})$} \\
\hline I & & 0 day $(\mathrm{g})$ & $15^{\text {th }}$ day $(\mathrm{g})$ \\
\hline II & Normal control & $161.93 \pm 4.42$ & $167.59 \pm 0.29$ \\
\hline III & Diabetic control & $167.04 \pm 6.84$ & $138.54 \pm 1.09$ \\
\hline IV & Diabetic+ SC $(50 \mathrm{mg} / \mathrm{kgbw})$ & $166.01 \pm 2.17$ & $171.56 \pm 2.09 * *$ \\
\hline V & Diabetic+ SC $(100 \mathrm{mg} / \mathrm{kgbw})$ & $148.63 \pm 2.56$ & $164.66 \pm 3.90 *$ \\
\hline IV & Diabetic+ SC $(200 \mathrm{mg} / \mathrm{kgbw})$ & $149.46 \pm 0.85$ & $166.68 \pm 1.22^{*} *$ \\
\hline \multicolumn{2}{|c|}{ Diabetic+ Glibenclamide $(600 \mu \mathrm{g} / \mathrm{kg}$ bw) } & $158.46 \pm 1.75$ & $175.68 \pm 2.22^{*} *$ \\
\hline
\end{tabular}


Table 3: Effect of oral administration of SC methanol extract on plasma glucose levels in STZ induced diabetic rats (Mean \pm SEM).

\begin{tabular}{|c|c|c|c|c|}
\hline $\begin{array}{c}\text { Groups } \\
(\mathbf{n = 6}) \\
\text { Treatment }\end{array}$ & Treatment & & \multicolumn{2}{c|}{ Plasma glucose levels (mg/dL) } \\
\cline { 3 - 5 } & & 0 day $(\mathrm{g})$ & $7^{\text {th }}$ day $(\mathrm{g})$ & $15^{\text {th }}$ day $(\mathrm{g})$ \\
\hline I & Normal control & $74.93 \pm 1.42$ & $74.93 \pm 1.42$ & $75.59 \pm 1.29$ \\
\hline II & Diabetic control & $211.04 \pm 3.84$ & $234.04 \pm 2.84$ & $248.54 \pm 2.09$ \\
\hline III & Diabetic+ SC $(50 \mathrm{mg} / \mathrm{kgbw})$ & $207.01 \pm 1.17$ & $186.01 \pm 2.17$ & $166.56 \pm 2.09 * *$ \\
\hline IV & Diabetic+ SC $(100 \mathrm{mg} / \mathrm{kgbw})$ & $209.63 \pm 1.56$ & $166.63 \pm 1.56$ & $145.66 \pm 2.90 * *$ \\
\hline V & Diabetic+ SC $(200 \mathrm{mg} / \mathrm{kgbw})$ & $210.46 \pm 1.85$ & $157.46 \pm 0.85$ & $114.68 \pm 1.22^{* *}$ \\
\hline IV & Diabetic+ Glibenclamide $(600 \mu \mathrm{g} / \mathrm{kg}$ bw) & $205.46 \pm 1.75$ & $155.46 \pm 0.75$ & $102.68 \pm 1.22 * *$ \\
\hline
\end{tabular}

** Values deviate very significantly $(P \leq 0.05)$ when compared with diabetic control values.

Table 4: Effect of oral administration of SC methanol extract on plasma insulin levels in STZ induced diabetic rats (Mean \pm SEM).

\begin{tabular}{|c|c|c|c|}
\hline $\begin{array}{c}\text { Groups } \\
(\mathbf{n = 6}) \\
\text { Treatment }\end{array}$ & Treatment & \multicolumn{2}{|c|}{ Plasma Insulin $(\boldsymbol{\mu U} / \mathbf{m L})$} \\
\hline I & & Zero day & Final day \\
\hline II & Normal control & $128.93 \pm 0.42$ & $131.59 \pm 1.29$ \\
\hline III & Diabetic control & $48.04 \pm 0.84$ & $55.54 \pm 1.09$ \\
\hline IV & Diabetic+ SC $(50 \mathrm{mg} / \mathrm{kgbw})$ & $47.01 \pm 1.17$ & $71.56 \pm 2.09 * *$ \\
\hline V & Diabetic+ SC $(100 \mathrm{mg} / \mathrm{kgbw})$ & $50.63 \pm 1.56$ & $86.66 \pm 1.90 *$ \\
\hline IV & Diabetic+ SC $(200 \mathrm{mg} / \mathrm{kgbw})$ & $51.46 \pm 1.85$ & $114.68 \pm 1.22 * *$ \\
\hline
\end{tabular}

* Values deviate significantly from diabetic control; ** Values deviate very significantly $(P \leq 0.05)$ when compared with diabetic control values.

Table 5: Effect of oral administration of SC methanol extract on glycosylated hemoglobin, liver glycogen and muscle glycogen in STZ induced diabetic rats after 15 days (Mean \pm SEM).

\begin{tabular}{|c|c|c|c|c|}
\hline $\begin{array}{c}\text { Groups } \\
(\mathbf{n = 6}) \\
\text { Treatment }\end{array}$ & Treatment & $\begin{array}{c}\text { Glycosylated } \\
\text { hemoglobin } \\
\mathbf{( \% )}\end{array}$ & $\begin{array}{c}\text { Liver glycogen } \\
\text { (mg/g wet tissue) }\end{array}$ & $\begin{array}{c}\text { Muscle glycogen } \\
\text { (mg/g wet tissue) }\end{array}$ \\
\hline I & Normal control & $4.00 \pm 0.13$ & $54.05 \pm 0.93$ & $7.53 \pm 0.14$ \\
\hline II & Diabetic control & $8.25 \pm 0.53$ & $17.93 \pm 0.37$ & $2.57 \pm 0.16$ \\
\hline III & Diabetic+ SC $(50 \mathrm{mg} / \mathrm{kgbw})$ & $6.81 \pm 0.15^{*}$ & $23.23 \pm 1.27$ & $3.39 \pm 0.13$ \\
\hline IV & Diabetic+ SC $(100 \mathrm{mg} / \mathrm{kgbw})$ & $5.29 \pm 0.35^{*}$ & $29.53 \pm 0.45^{* *}$ & $5.79 \pm 0.08^{* *}$ \\
\hline V & Diabetic+ SC $(200 \mathrm{mg} / \mathrm{kgbw})$ & $4.79 \pm 0.27 * *$ & $38.85 \pm 0.63^{* *}$ & $7.47 \pm 0.17 * *$ \\
\hline IV & Diabetic+ Glibenclamide $(600 \mu \mathrm{g} / \mathrm{kg}$ bw) & $4.33 \pm 0.25^{* *}$ & $47.17 \pm 0.65^{* *}$ & $8.49 \pm 0.19 * *$ \\
\hline
\end{tabular}

* Values deviate significantly from diabetic control; **Values deviate very significantly $(P \leq 0.05)$ when compared with diabetic control values.

Table 6: Effect of oral administration of SC methanol extract on lipid profile in STZ induced diabetic rats after 15 days (Mean \pm SEM).

\begin{tabular}{|c|c|c|c|c|}
\hline \multirow{2}{*}{$\begin{array}{c}\text { Groups } \\
(\mathbf{n}=6) \\
\text { Treatment }\end{array}$} & Treatment & \multicolumn{3}{|c|}{ Lipid profile (mg/dL) } \\
\cline { 3 - 5 } & & $\begin{array}{c}\text { Total } \\
\text { cholesterol }\end{array}$ & Triglyceride & HDL \\
\hline I & Normal control & $54.93 \pm 2.42$ & $45.93 \pm 2.42$ & $72.59 \pm 2.29$ \\
\hline II & Diabetic control & $116.04 \pm 3.84$ & $134.04 \pm 6.84$ & $28.54 \pm 1.09$ \\
\hline III & Diabetic+ SC (50mg/kgbw) & $107.01 \pm 2.17 *$ & $96.01 \pm 3.17 * *$ & $71.56 \pm 3.09 * *$ \\
\hline IV & Diabetic+ SC (100mg/kgbw) & $98.63 \pm 1.56 * *$ & $91.63 \pm 1.56 * *$ & $74.66 \pm 2.90^{* *}$ \\
\hline V & Diabetic+ SC $(200 \mathrm{mg} / \mathrm{kgbw})$ & $94.46 \pm 1.85^{* *}$ & $79.46 \pm 5.85^{* *}$ & $75.68 \pm 1.22^{* *}$ \\
\hline IV & Diabetic+ Glibenclamide $(600 \mu \mathrm{g} / \mathrm{kg}$ bw) & $93.46 \pm 2.75^{* *}$ & $111.46 \pm 1.75^{* *}$ & $75.68 \pm 1.22^{* *}$ \\
\hline
\end{tabular}

* Values deviate significantly from diabetic control; ** values deviate very significantly $(P \leq 0.05)$ when compared with diabetic control values. 
Table 7: Effect of oral administration of SC methanol extract on serum marker enzymes in STZ induced diabetic rats after 15 days (Mean \pm SEM).

\begin{tabular}{|c|c|c|c|c|}
\hline \multirow{2}{*}{$\begin{array}{c}\text { Groups } \\
(n=6) \\
\text { Treatment }\end{array}$} & \multirow[t]{2}{*}{ Treatment } & \multicolumn{3}{|c|}{ Serum marker enzymes $(\mu / L)$} \\
\hline & & SGOT & SGPT & ALP \\
\hline I & Normal control & $62.93 \pm 0.42$ & $67.93 \pm 1.42$ & $122.59 \pm 1.29$ \\
\hline II & Diabetic control & $153.04 \pm 2.84$ & $156.04 \pm 1.84$ & $243.54 \pm 1.09$ \\
\hline III & Diabetic+ SC (50mg/kgbw) & $123.01 \pm 1.17 * *$ & $118.01 \pm 1.17 * *$ & $171.56 \pm 1.09 * *$ \\
\hline IV & Diabetic+ SC (100mg/kgbw) & $95.63 \pm 0.56 * *$ & $93.63 \pm 1.56^{* *}$ & $138.66 \pm 0.90 * *$ \\
\hline $\mathbf{V}$ & Diabetic+ SC (200mg/kgbw) & $66.46 \pm 1.85^{* *}$ & $75.46 \pm 2.85^{* *}$ & $125.68 \pm 1.22 * *$ \\
\hline IV & $\begin{array}{l}\text { Diabetic }+ \text { Glibenclamide }(600 \mu \mathrm{g} / \mathrm{kg} \\
\text { bw) }\end{array}$ & $64.46 \pm 1.75^{* *}$ & $66.46 \pm 1.75^{* *}$ & $125.68 \pm 2.22 * *$ \\
\hline
\end{tabular}

** Values deviate very significantly $(P \leq 0.05)$ when compared with diabetic control values.

\section{DISCUSSION:}

The present study for the first time reports the antidiabetic and hypolipidemic effect of SC methanol extract in STZ induced diabetic rats. STZ in one of the most commonly used substances to induce diabetes in rats. This toxin causes the death of pancreatic $\beta$-cell by alkylation of DNA resulting in reduced synthesis and release of insulin. Furthermore, it has been shown to be involved in the fragmentation of DNA by means of production of reactive oxygen species ${ }^{16,17}$.

Induction of diabetes by STZ leads to loss of body weight due to the increased muscle wasting and loss of tissue proteins ${ }^{18}$. Administration of SC methanol extract for 15 days significantly increased the body weight when compared with diabetic control in dose dependent manner. When SC methanol extract was administered to glucose loaded normal rats fasted for $18 \mathrm{~h}$, hypoglycemia was observed after $30 \mathrm{~min}$. The decline in blood sugar level reached its maximum at $2 \mathrm{~h}$. The observed significant increase in the level of blood glucose and significant decrease in the level of plasma insulin in diabetic rats could be due to the destruction of pancreatic $\beta$ - cells by $\mathrm{STZ}^{19}$. Oral capacity of SC methanol extract to decrease the elevated blood sugar to normal glycemic level is an essential trigger for the liver to revert to its normal homeostasis during experimental diabetes. The possible mechanism by which SC methanol extract bring about its hypoglycemic action in diabetic rats may be improving glycemic control mechanism and insulin secretion from remnant pancreatic beta cells in diabetic rats ${ }^{20}$, as it is evidenced by the significant increase in the level of insulin in treated rats by SC methanol extract (200 $\mathrm{mg} / \mathrm{kg} \mathrm{bw}$ ).

Phytochemical investigation of SC methanol extract reveals the presences of Carbohydrate, Proteins, Sterols, Saponin, Coumarins, Lipid and flavonoids. These principles are known to be bioactive for the management of diabetes. It is well known that certain flavonoids exhibit hypoglycemic activity and pancreas beta cell regeneration ability. Sterols have also shown to decrease blood sugar in experimental animal models ${ }^{21}$. Thus, the significant antidiabetic effect of aqueous SC extract may be due to the presence of more than one antihyperglycemic principle and their synergistic properties.

Insulin is the main regulator of glycogenesis in muscle and liver. The decrease of liver glycogen level observed in this study may be due to lack of insulin in diabetic condition or oxidative stress which may inactivate the glycogen synthetase ${ }^{22}$. The marked reduction in liver and muscle glycogen level is observed (15 days) in streptozotocin induced diabetic animals. Treatment with SC methanol extract remarkably increased the glycogen level in liver and muscle. In the view of glycogen level, there may be three possible ways of antidiabetic action; one possible way may be increased insulin level by preventing the inactivation of the glycogen synthetase and by synthesize the glycogen synthatase ${ }^{23}$. The typical characteristics of diabetes is the increase of serum glycated protein such as glycated hemoglobin (HbA1C), which is a parameter for glycemic control where glucose or other reducing sugars react with the amino residues of proteins to form Amadori products such as glycated hemoglobin ${ }^{24}$. Animals treated with SC methanol extract significantly decreased the glycosylated hemoglobin level which could be due to an improvement in insulin secretion from the remnant pancreatic beta cells in diabetic rats ${ }^{25}$.

Since lipid abnormalities accompanying with premature atherosclerosis is the major cause of cardiovascular diseases in diabetic patients, therefore ideal treatment for diabetes, in addition to glycemic control, should have a favorable effect on lipid profile. Cardiovascular diseases are listed as the cause of death in $65 \%$ people suffering from diabetes ${ }^{26-31}$. From this point of view, it is encouraging that the 15 day treatment of SC methanol extract brought down the elevated level of lipid profile such as total cholesterol, triglycerides to near normal level. There was increase in HDL-cholesterol also, which was desirable feature.

HDL-cholesterol also, which was desirable feature. Liver is the vital organ of metabolism, detoxification, storage and excretion of xenobiotics and their metabolites. SGOT, SGPT and ALP are reliable markers of liver function. The liver was necrotized in STZ-induced diabetic rats. Therefore an increase in the activities of SGOT, SGPT and ALP in plasma might be 
mainly due to the leakage of these enzymes from the liver cytosol into the blood stream which gives an indication of the hepatotoxic effect of STZ ${ }^{32}$. Treatment of the diabetic rats with the SC methanol extract caused reduction in the activity of these enzymes in plasma compared to the diabetic control group and consequently alleviated liver damage caused by STZ-induced diabetes. These results are in agreement with those obtained by Eliza $e t a l^{33}$.

Histopathology studies also supported our findings. STZ was suspected to destroy pancreas partially. Diabetic rats showed reduced islet cells, which were restored to near normal upon treatment with the SC methanol extract. No such changes were found in the normal rats.

The findings of this study indicate that consumption of SC methanol extract exerts significant antidiabetic and hypolipidemic effect in STZ-induced diabetic rats. Histopathological studies of the pancreas of SC methanol extract treated diabetic rats show evidence of signs of regeneration of $\beta$-cells. Longer duration studies of S. Colais and its isolated compounds on chronic models are necessary to elucidate the exact mechanism of action so as to develop it as a potent antidiabetic drug.

\section{CONFLICT OF INTEREST STATEMENT:}

We declare that we have no conflict of interest.

\section{ACKNOWLEDGEMENTS:}

Authors thank, Department of Pharmaceutical Sciences, JJT University \& Oriental college of Pharmacy, for providing facilities to conduct this research work.

\section{REFERENCES:}

[1] Qaseem A et al, Oral pharmacologic treatment of type 2 diabetes mellitus: a clinical practice guideline from the American College of Physicians. Annals of Internal Medicine, 2012; 156(3): 218-231.

[2] Fonseca VA. Clinical diabetes: Translating research into practice. Philadelphia: Saunders Elsevier: 2006; 2-3.

[3] kanchana G, Malini P, Rajadurai M, Antibiabetic Efficacy of Ellagic Acid in Streptozotocin induced Diabetes Mellitus in albino wistar rats, Asian Journal of Pharmaceutical and Clinical Research, 2011; 4(3): 124-128.

[4] Pari L and Latha M, Effect of Cassia auriculata flowers on Blood Sugar Levels, Serum Tissue Lipids in Streptozotocin Diabetic rats, Singapore Medical Journal, 2002; 43: 617-621.

[5] Chaterjee A, The treatise on Indian medicinal plants. Published by National institute of science communication and information resources, 1997; 5: 46-47.

[6] Vaidya SA, Indian medicinal plants a compendium of 500 species, published by orient Longman private limited, 1996; 5 : 192.

[7] Khadabadi SS, Deore SL, Baviskar BA, Experimental Phytopharmacognosy, $1^{\text {st }}$ edition, Published by Nirali prakashan. $2011 ; 3.2-3.8,4.29-4.33$.

[8] Ghosh MN. Fundamentals of experimental pharmacology. Calcutta: Scientific Book Agency. 1984; 153.

[9] Turner MA. Screening methods in pharmacology. NewYork: Academic Press. 1965; 26.

[10] Bonner-Weir S. Morphological evidence for pancreatic polarity of beta-cells within islets of langerhans. Diabetes. 1988; 37(5): 616-621.

[11] Triender P. Determination of glucose using glucose oxidase with an alternative oxygen acceptor. Ann Clin Biochem. 1969; 6: 24-27.

[12] Carrol NV, Longley RW, Roe JH. The determination of glycogen in liver and muscle by use of anthrone reagent. J Biol Chem. 1956; 220(2): 583-593.

[13] Sudhakar NS, Pattabiraman TN. A new colorimetric method for the estimation of glycosylated haemoglobin. Clin Chim Acta. 1981; 109(3): 267-274.

[14] Reitman S, Frankel S. Colorimetric method for the determination of serum glutamic oxaloacetic acid and glutamic pyruvic transaminases. Am J Clin Pathol 1957; 28(1): 56-63.
[15] Nirmala A, Saroja S, Vasanthi HR, Lalitha G. Hypoglycemic effect of Basella rubra in streptozotocin- induced diabetic albino rats. J Pharmacog Phytother 2009; 2: 25-30.

[16] Mahimainathan L, Das F, Venkatesan B, Choudhury GG. Mesangial cell hypertrophy by high glucose is mediated by down regulation of the tumor suppressor PTEN. Diabetes 2006; 55: 2115-2125.

[17] Rao NK, Nammi S. Antidiabetic and renoprotective effects of the chloroform extract of Terminalia chebula Retz. seeds in streptozotocin-induced diabetic rats. BMC Comp Alt Med 2006; 6: 17.

[18] Shirwaikar A, Rajendran K, Barik R. Effect of aqueous bark extract of Garuga pinnata Roxb. in streptozotocin-nicotinamide induced type-II diabetes mellitus. J Ethnopharmacol 2006; 107: 285-290.

[19] Dimo T, Rakotonirina SV, Tan PV, Azay J, Dongo E, KamtchouingP, et al. Effect of Sclerocarya birrea (Anacardiaceae) stem bark methylene chloride/methanol extract on streptozotocin-diabetic rats. J Ethnopharmacol 2007; 110(3): 434-438.

[20] Punitha R, Manohara S. Antihyperglycemic and antilipidperoxidative effects of Pongamia pinnata (Linn.) Pierre flowers in alloxan induced diabetic rats. J Ethnopharmacol 2006; 105: 39-46.

[21] Singh SK, Kesari AN, Gupta RK, Jaiswal D, Watal G. Assessment of antidiabetic potential of Cynodon dactylon extract in streptozotocin diabetic rats. J Ethnopharmacol 2007; 114:174179 .

[22] Daisy P, Balasubramanian K, Rajalakshmi M, Eliza J, Selvaraj J. Insulin mimetic impact of Catechin isolated from Cassia fistula on the glucose oxidation and molecular mechanisms of glucose up take on streptozotocin-induced diabetic Wistar rats. Phytomedicine 2010; 17: 28-36.

[23] Selvan VT, Mani Kandan L, Senthil Kumar GP, Suresh R, Kumar DA, Mazumdar UK. Antidiabetic and antioxidant effect of methanol extract Artanema Sesamoides in streptozotocin induced diabetic rats. Int J Appl Res Nat Prod 2008; 1(1): 25-33.

[24] Michela CG, Nesseemb DI, Ismailc MF. Anti-diabetic activity and stability study of the formulated leaf extract of Zizyphus spina-christi (L.) Willd with the influence of seasonal variation. J Ethnopharmacol 2011; 133: 53-62.

[25] Kondeti VK, Badri KR, Maddirala DR, Thur SKM, Fatima SS, Kasetti RB, et al. Effect of Pterocarpus santalinus bark, on 
blood glucose, serum lipids, plasma insulin and hepatic carbohydrate metabolic enzymes in streptozotocin-induced diabetic rats. Food Chem Toxicol 2010; 48: 1281-1287.

[26] Kesari AN, Kesari S, Singh SK, Gupta RK, Watal G. Studies on the glycemic and lipidemic effect of Murraya koenigii in experimental animals. J Ethnopharmacol 2007; 112: 305-311.

[27] Kumar S, Kumar V, Prakash O. Antidiabetic, hypolipidemic and histopathological analysis of Dillenia indica (L.) leaves extract on alloxan induced diabetic rats. Asian Pac J Trop Med 2011; 4(5): 347-352.

[28] Patil R, Patil R, Ahirwar B, Ahirwar D. Isolation and characterization of anti-diabetic component (bioactivity-guided fractionation) from Ocimum sanctum L. (Lamiaceae) aerial part. Asian Pac J Trop Med 2011; 4(4): 278-282.

[29] Patil RN, Patil RY, Ahirwar B, Ahirwar D. Evaluation of antidiabetic and related actions of some Indian medicinal plants in diabetic rats. Asian Pac J Trop Med 2011; 4(1): 20-23.
[30] Kumar S, Kumar V, Prakash O. Antidiabetic and antilipemic effects of Cassia siamea leaves extract in streptozotocin induced diabetic rats. Asian Pac J Trop Med 2010; 3(11): 871873.

[31] Osadebe PO, Omeje EO, Nworu SC, Esimone CO, Uzor PF, David EK, et al. Antidiabetic principles of Loranthus micranthus Linn. parasitic on Persea americana. Asian Pac J Trop Med 2010; 3(8): 619-623.

[32] Kasetti RB, Rajasekhar MD, Kondeti VK, Fatima SS, Kumar EGT, Swapna S, et al. Antihyperglycemic and antihyperlipidemic activities of methanol: water $(4: 1)$ fraction isolated from aqueous extract of Syzygium alternifolium seeds in streptozotocin induced diabetic rats. Food Chem Toxicol 2010; 48: $1078-1084$.

[33] Eliza J, Daisy P, Ignacimuthu S, Duraipandiyan V. Normoglycemic and hypolipidemic effect of costunolide isolated from Costus speciosus (Koen ex. Retz.) Sm. in streptozotocininduced diabetic rats. Chem Biol Interact 2009; 179: 329-334

\section{* Correspondence Author:}

Mohammed Imran

Associate Professor, Department of Quality Assurance, K.B.H.S.S. Trust's Institute of Pharmacy, Malegaon Camp, Dist. Nasik (M.S.), India, Mobile: 09970929176, Email: imransa99@ rediffmail.com

\section{How to cite this article:}

Imran MD, Khan M, Akhtar R, Ahmed S, Rageeb M, Antidiabetic and hypolipidemic effect of methanol extract of stereospermum colais fruit in streptozotocin induced diabetic rats, Journal of Drug Delivery \& Therapeutics. 2016; 6(4):31-36 